\title{
Hakekat Ilmu Pengetahuan dalam Persfektif Islam
}

\author{
Abdul Mujib \\ Institut Agama Islam Negeri Metro \\ email: abdulmujib@metrouniv.ac.id
}

\begin{abstract}
Abstrak
Ilmu pengetahuan merupakan seluruh usaha sadar untuk menyelidiki, menemukan, dan meningkatkan pemahaman manusia dari berbagai segi kenyataan dalam alam manusia. Segi-segi ini dibatasi agar dihasilkan rumusanrumusan yang pasti. Ilmu memberikan kepastian dengan membatasi lingkup pandangannya, dan kepastian ilmu-ilmu diperoleh dari keterbatasannya.Ilmu bukan sekadar pengetahuan tetapi merangkum sekumpulan pengetahuan berdasarkan teori-teori yang disepakati dan dapat secara sistematik diuji dengan seperangkat metode yang diakui dalam bidang ilmu tertentu. Dipandang dari sudut filsafat, ilmu terbentuk karena manusia berusaha berfikir lebih jauh mengenai pengetahuan yang dimilikinya. Ilmu pengetahuan adalah produk dari istemologepi. Ilmu pengetahuan adalah seluruh usaha sadar untuk menyelidiki, menemukan, dan meningkatkan pemahaman manusia dari berbagai segi kenyataan dalam alam manusia. Segi-segi ini dibatasi agar dihasilkan rumusanrumusan yang pasti. Ilmu memberikan kepastian dengan membatasi lingkup pandangannya, dan kepastian ilmu-ilmu diperoleh dari keterbatasannya.
\end{abstract}

Kata Kunci : Ilmu Pengetahuan, Islam

\section{Pendahuluan}

Asal kata ilmu adalah dari bahasa Arab, 'alama. Arti dari kata ini adalah pengetahuan. Dalam bahasa Indo-nesia, ilmu sering disamakan dengan sains yang berasal dari bahasa Inggris "science". Kata "science" itu sendiri berasal dari bahasa Yunani yaitu "scio", "scire" yang artinya pengetahuan. "Science"dari bahasa Latin "scientia", yang berarti "pengetahuan" adalah aktivitas yang sistematis yang membangun dan mengatur pengetahuan dalam bentuk penjelasan dan prediksi tentang alam semesta. Berdasarkan Oxford Dictionary, ilmu didefinisikan sebagai aktivitas intelektual dan praktis yang meliputi studi sistematis tentang struktur dan perilaku dari dunia fisik dan alam melalui pengamatan dan percobaan".

Dalam kamus bahasa Indonesia ilmu didefinisikan sebagai pengetahuan tentang suatu bidang yang disusun secara bersistem menurut metode tertentu, yang dapat digunakan untuk menerangkan gejala tertentu di bidang pengetahuan. Pengertian ilmu pengetahuan adalah sebuah sarana atau definisi tentang alam semesta yang diterjemahkan kedalam bahasa yang bisa dimengerti oleh manusia sebagai usaha untuk mengetahui dan mengingat tentang sesuatu. Dengan ilmu maka hidup menjadi mudah, karena ilmu juga merupakan alat untuk menjalani kehidupan. Berdasarkan definisi di atas dapat disimpulkan bahwa ilmu bukan sekedar pengetahuan (knowledge), tetapi merupakan rangkuman dari sekumpulan pengetahuan berdasarkan teori-teori yang disepakati/berlaku umum dan diperoleh melalui serangkaian prosedur sistematik, diuji dengan seperangkat metode yang diakui dalam bidang ilmu tertentu. 
Ilmu adalah merupakan suatu pengetahuan, sedangkan pengetahuan merupakan informasi yang didapatkan dan segala sesuatu yang diketahui manusia. Itulah bedanya dengan ilmu, karena ilmu itu sendiri merupakan pengetahuan yang berupa informasi yang didalami sehingga menguasai pengetahuan tersebut yang menjadi suatu ilmu.

Ilmu pengetahuan merupakan rangkaian kata yang sangat berbeda namun memiliki kaitan yang sangat kuat. Ilmu dan pengetahuan memang terkadang sulit dibedakan oleh sebagian orang karena memiliki makna yang berkaitan dan sangat berhubungan erat. Membicarakan masalah ilmu pengetahuan dan definisinya memang sebenarnya tidak semudah yang diperkirakan. Adanya berbagai definisi tentang ilmu pengetahuan ternyata belum dapat menolong untuk memahami hakikat ilmu pengetahuan itu.

Sedangkan dalam kamus Bahasa Indonesia, ilmu merupakan pengetahuan tentang suatu bidang yang disusun secara bersistem menurut metode tertentu, yang dapat digunakan untuk menerangkan gejala - gejala tertentu tersebut. Mulyadhi Kartanegara mengatakan ilmu adalah any organized knowledge. Ilmu dan sains menurutnya tidak berbeda, terutama sebelum abad ke19 , tetapi setelah itu sains lebih terbatas pada bidang-bidang fisik atau inderawi, sedangkan ilmu melampauinya pada bidang-bidang non fisik, seperti metafisika.

Adapun beberapa definisi ilmu menurut para ahli seperti yang dikutip oleh Bakhtiar tahun 2005 diantaranya adalah:

1. Mohamad Hatta, mendefinisikan ilmu adalah pengetahuan yang teratur tentang pekerjaan hukum kausal dalam suatu golongan masalah yang sama tabiatnya, maupun itu menurut kedudukannya tampak dari luar, maupun menurut bangunannya dari dalam.

2. Ralph Ross dan Ernest Van Den Haag, mengatakan ilmu adalah yang empiris, rasional, umum dan sistematik, dan ke empatnya serentak.

3. Karl Pearson, mengatakan ilmu adalah lukisan atau keterangan yang komprehensif dan konsisten tentang fakta pengalaman dengan istilah yang sederhana.

4. Ashley Montagu, menyimpulkan bahwa ilmu adalah pengetahuan yang disusun dalam satu sistem yang berasal dari pengamatan, studi dan percobaan untuk menentukan hakikat prinsip tentang hal yang sedang dikaji.

5. Harsojo menerangkan bahwa ilmu merupakan akumulasi pengetahuan yang disistemasikan dan suatu pendekatan terhadap seluruh dunia empiris yaitu dunia yang terikat oleh faktor ruang dan waktu, dunia yang pada prinsipnya dapat diamati oleh pancaindrea manusia.

6. Afanasyef, menyatakan ilmu adalah manusia tentang alam, masyarakat dan pikiran. Ia mencerminkan alam dan konsep-konsep, kategori dan hokum-hukum, yang ketetapannya dan kebenarannya diuji dengan pengalaman praktis.

Beberapa definisi ilmu yang dijelaskan para ahli di atas dapat disimpulkan bahwa ilmu merupakan pengetahuan yang rasional, sistematik, konfrehensif, konsisten, dan bersifat umum tentang fakta dari pengamatan yang telah dilakukan. Pengetahuan adalah keseluruhan ilmu pengetahuan yang belum tersusun, baik mengenai matafisik maupun fisik. Dapat juga dikatakan pengetahuan adalah informasi yang ada dan berupa common sense, tanpa memiliki metode, dan mekanisme tertentu. Pengetahuan berakar pada adat dan 
tradisi yang menjadi kebiasaan dan pengulangan-pengulangan. Dalam hal ini landasan pengetahuan kurang kuat cenderung kabur dan samar-samar. Pengetahuan tidak teruji karena kesimpulan ditarik berdasarkan asumsi yang tidak teruji lebih dahulu. Pencarian pengetahuan lebih cendrung trial and error dan berdasarkan pengalaman belaka.

\section{Pembahasan}

Secara lebih jelas, ilmu seperti sapu lidi, yakni sebagian lidi yang sudah diraut dan dipotong ujung dan pangkalnya kemudian diikat, sehingga menjadi sapu lidi. Sedangkan pengetahuan adalah lidi-lidi yang masih berserakan di pohon kelapa, di pasar, dan tempat lainnya yang belum tersusun dengan baik. Jadi, dari asumsi-asumsi, pendapat-pendapat yang telah dikumpulkan, maka lmu pengetahua dapat didefinisikan sebagai seluruh usaha sadar untuk menyelidiki, menemukan, dan meningkatkan pemahaman manusia dari berbagai segi kenyataan dalam alam manusia. Segi-segi ini dibatasi agar dihasilkan rumusan-rumusan yang pasti. Ilmu memberikan kepastian dengan membatasi lingkup pandangannya, dan kepastian ilmu yang ada dan diperoleh dari keterlibatannya.

Maka, gejala inilah yang disebut gejala mengetahui, gejala yang kemudian melahirkan sebuah pengetahuan (filsafat) bagi manusia. Pengetahuan yang merupakan segala sesuatu yang diketahui manusia. Gejala yang lahir dalam diri manusia karena adanya potensi untuk mengetahui dengan menggunakan akalnya untuk mengetahui segala sesuatu yang tidak diketahui, mencari, berupaya, dan akhirnya menganalisis pengetahuan yang didapatnya untuk memenuhi kebutuhan dan keinginannya. Jika pengetahuan tersebut dapat memuaskan manusia, maka disebut pengetahuan yang benar. Namun pengetahuan yang tidak benar disebut kekeliruan. Keliru tersebut seringkali lebih jelek dari pada tidak tahu dan dapat menghasilkan perbuatan yang salah dan menjadi malapetaka bagi manusia.

Adapun pengelompokan manusia dari hasil gejala mengetahui yakni:

1. Manusia tahu, bahwa ia tahu. Maksudnya manusia mengetahui bahwa dirinya mengetahui suatu objek pengetahuan.

2. Manusia tahu, bahwa ia tidak tahu. Maksudnya manusia mengetahui bahwa ia tidak mengetahui tentang suatu objek pengetahuan tersebut.

3. Manusia tidak tahu, bahwa ia tahu. Maksudnya manusia tidak mengetahui/ tidak sadar bahwa dirinya sebenarnya tahu mengenai suatu objek tersebut.

4. Manusia tidak tahu, bahwa ia tidak tahu. Manusia inilah yang disebut manusia yang sok tahu, karena ia tidak mengetahui bahwa dirinya tidak tahu akan suatu objek tersebut.

Pengetahuan merupakan hasil dari keingintahuan manusia dengan suatu subjek yang ingin diketahuinya. Pada hakikatnya, manusia memahami secara. sederhana apa itu pengetahuan namun yang menjadi masalahnya tidak semua manusia dapat mendefinisikan dengan baik pengetahuan ilmu pengetahuan itu. Karena sebenarnya, pengetahuan itu timbul karena manusianya sendiri yang mencari tahu. Ilmu kadang memiliki makna sebagai sesuatu yang dimiliki seseorang setelah ia mempelaja-rinya, sementara pengetahuan adalah apa yang diketahuinya. Hakikat pengetahuan menurut aliran yang berkembang yakni, 
1. Idealisme: Para penganut aliran idealisme berpandangan bahwa pengetahuan adalah proses-proses mental dan psikologis yang bersifat subyektif. Oleh karena itu, pengetahuan tidak lain merupakan gambaran subyektif tentang suatu kenyataan. Menurut mereka, pengetahuan tidak memberikan gambaran sebenarnya tentang kenyataan yang berada di luar pikiran manusia.

2. Empirisme: Tentang asal-usul pengetahua para penga-nut aliran ini mengatakan bahwa pengetahuan berasal dari pengalaman indra. Tentang hakikat pengetahuan, mereka mengatakan bahwa pengetahuan adalah pengalaman. Seorang tokoh empirisme radikal adalah David Hume. Dia berpendapat bahwa ide-ide dapat dikembalikan kepada sensasi-sensasi (rangsang indra). Pengalaman merupakan ukuran terakhir dari kenyataan. Apa yang dialami, itulah pengetahuan.

3. Positivisme: Kalau idealisme dapat dianggap sebagai kelanjutan dari rasionalisme, maka hal positivime merupakan sesuatu perpanjangan dari empirisme. Para penga-nut aliran ini menolak kenyataan di luar pengalaman. Mereka juga mengatakan bahwa kepercayaan yang berdasarkan dogma harus digantikan pengetahuan yang berdasarkan fakta.

4. Pragtisme: Tokoh-tokoh aliran ini antara lain Willian James, John Dewey, dan C.S. Pierce. Menurut aliran ini, hakikat pengetahuan terletak dalam manfaat praktisnya adalah bagi kehidupan. Pengetahuan adalah sarana bagi perbuatan. C.S. Pierce mengatakan bahwa yang penting adalah pengaruh sebuah ide atau pengetahuan bagi sebuah rencana lain. Nilai sebuah pengetahuan akan tergantung pada penerapannya secara konkrit dalam kehidupan masyarakat tersebut. Suatu pengetahuan itu benar bukan karena ia mencerminkan kenyataan obyektif, melainkan karena ia bermanfaat bagi umum. Menurut William James, ukuran kebenaran ditentukan oleh akibat praktisnya. Sedangkan John Dewey menegaskan bahwa tidak perlu mempersoalkan kebenaran suatu pengetahuan, tapi sejauh mana pengetahuan memecahkan persoalan yang dihadapi masyarakat.

Masalah terjadinya pengetahuan adalah masalah yang amat penting dalam epistemologi, sebab jawaban terhadap terjadinya pengetahuan maka seseorang akan berwarna pandangan atau paham filsafatnya.

Secara umum dapat digambarkan secara baik pengetahuan terdiri atas:

1. Pengetahuan non ilmiah/ pengetahuan biasa (common sense)

Pengetahuan non ilmiah ialah pengetahuan yang diperoleh dengan menggunakan cara-cara yang tidak termasuk dalam kategori metode ilmiah. Secara umum pengetahuan non ilmiah ialah hasil pemahaman manusia mengenai suatu objek tertentu yang terdapat dalam kehidupan sehari-hari.

2. Pengetahuan ilmiah

Pengetahuan ilmiah ialah segenap hasil pemahaman manusia yang diperoleh dengan menggunakan metode ilmiah. Pengetahuan ilmiah adalah suatu pengetahuan yang sudah lebih sempurna karena telah mempunyai dan memenuhi syarat tertentu dengan cara berpikir yang khas, yaitu metodologi ilmiah.

3. Pengetahuan noesis (filsafat) 
Pengetahuan Noesis (filsafat) adalah pengetahuan yang tidak mengenal batas, sehingga yang dicari adalah sebab-sebab yang paling hakiki. Pengetahuan yang berminat mencapai pengetahuan kebanaran yang asli yang mengandung ilmu-ilmu metafisika, logika, retorika, etika, ekonomi, politik, dan estetika atau pengetahuan yang objeknya adalah arche ialah prinsip utama yang mencakup epistemo-logik dan metafisik, ontologi dan aksionlogi.

4. Pengetahuan agama

Definisi Pengetahuan agama adalah pengetahuan yang hanya diperoleh dari Tuhan melalui para Nabi dan Rasul-Nya yang bersifat mutlak dan wajib diikuti para pemeluknya. Menjadi tolak ukur kebenaran dalam suatu keyakinan dan perpegang pada kitab yang dipegang para pememluknya.

Kebenaran adalah pernyataan tanpa ragu. Pembuktian kebenaran pengetahuan berdasarkan penalaran akal atau rasional atau menggunakan logika deduktif. Premis dan proposisi sebelumnya menjadi acuan berpikir rasionalisme. Kelemahan logika deduktif ini sering pengetahuan yang diperoleh tidak sesuai dengan fakta. Namun pada dasarnya, manusia mempe-roleh pengetahuan dari empat sumber yakni empirisme, rasionalisme, intuisi, dan wahyu.

1. Empirisme, merupakan manusia yang mendasarkan dirinya kepada pengalaman yang mengembangkan paham. Menganggap bahwa dunia fisik adalah nyata karena merupakan gejala yang tertangkap oleh pancaindera. Tokoh-tokohnya antara lain John Locke, Barkeley, David Hume. Para penganut aliran empirisme tentu saja menentang suatu kaum rasionalis yang begitu memberikan tempat dan peranan bagi akal dalam proses lahirnya pengetahuan. Mereka mengajarkan bahwa pengetahuan diperoleh lewat pengalaman. Peran rasio dalam pengetahuan kecil saja. Yang lebih menentukan adalah pengalaman indera. Akal hanya merupakan suatu tempat penampungan yang secara positif menerima apa yang diterima indra. John Locke, filsuf Inggris, misalnya menyebut manusia dengan tabula rasa (papan yang kosong). Di atas papan yang kosong inilah dicatat pengalaman-pengalaman yang masuk lewat indra.

2. Rasionalisme, merupakan kaum rasionalis yang mengembangkan paham rasionalisme, dasar kepastian dan kebenaran pengetahuan. Para penganut rasionalisme tidak menyangkal peran indra, tetapi mengatakan bahwa peran indra sangat kecil. Yang lebih aktif justru rasio. Mereka mengatakan, pengetahuan manusia sebenarnya sudah ada lebih dulu dalam rasio berupa kategori-kategori. Ketika indra manangkap objek, maka objek-objek yang ditangkap itu hanya dicocokkan saja dengan kategori yang sudah ada lebih dulu dalam rasio. Jadi menurut mereka, pengalaman adalah pelengkap bagi akal. Kaum ini menggunakan metode deduktif dalam menyusun pengetahuannya, idenya didapatkan dari anggapan-anggapan yang menurutnya jelas dan dapat diterima. Tokohtokohnya kebanyakan para filsuf abad pertengahan, seperti Agustinus, Johanes Scotus, Avicenna, dan para filsuf modern seperti Rene Descartes, Spinoza, Leibniz, Fichte, Hegel. Plato, Galileo Galilei dan Leonardo Da Vinci juga termasuk kelompok ini.

3. Intuisi, merupakan manusia yang memperoleh pengetahuan yang tanpa melalui proses penalaran tertentu. Tanpa melalui proses berpikir berliku- 
liku tiba-tiba saja dia sudah sampai disitu. Paham ini diajarkan oleh Henri Bergon, sering filsuf Prancis. Bergson membedakan suatu pengetahuan atas pengetahuan diskursif dan pengetahuan intuitif. Pengetahuan diskursif bersifat analitis, dan diperoleh melalui perantara simbol. Pengetahuan seperti ini dinyatakan dalam simbol, yakni bahasa.

4. Jadi, pengetahuan yang diperoleh dengan cara ini bersifat tidak langsung. Sebaliknya pengetahuan intuitif bersifat langsung, sebab tidak dikomunikasikan melalui media simbol. Pengetahuan ini diperoleh lewat intuisi, pengalaman langsung orang yang bersangkutan. Jelaslah, bahwa sifat pengetahuan dalam intuisionisme lebih subyektif dibanding pengetahuan rasionalis dan empiris yang lebih objektif.

5. Wahyu, merupakan pengetahuan yang bersumber dari Tuhan melalui hamba-Nya yang terpilih untuk menyampaikannya (Nabi atau Rasul). Melalui wahyu, manusia diajarkan tentang pengetahuan, baik yang terjangkau maupun tidak terjangkau oleh manusia.

Metode memperoleh pengetahuan, menentukan sifat kebenaran pengetahuan, yang terdiri dari:

1. Metode empirik (empirime)mendapat pengetahuan melalui pengalaman inderawi. Sedangkan akal-pikiran di pandang sebagai penampung segala apa yang dialami. Cara ini mengandung beberapa unsur, yaitu subjek yang mengetahui dan objek yang diketahui, dan proses bagaimana subjek berhubungan dengan objek (empirisme john locke). Cara ini bisa menjadi ekstern,apabila hanya mengakui bahwa sesuatu hal dapat disebut pengetahuan atau bukan itu tergantung pada apakah bisa dilacak kembali secara empirik atau tidak. Ini lalu menjadi "empirisme radikal".

2. Metode rasional (rationalisme) melihat pengetahuan bersumber dari akal pikiran. pengalaman dipandang sebagai perangsang bagi akalpikiran.kebenaran bukan terletak pada diri sesuatu, melainkan pada idea. Akal - pikiran secara deduktif bekerja untuk mendapatkan pengetahuan yang pasti,jadi akal pikiran berperan sebagai suatu tehnik deduktif (penalaran) dalam menentukan kebenaran.

3. Metode fenomenologik (fenomenolog-isme I.Kant). Bahwa apa yang dapat diketahui tentang sesuatu hal itu hanyalah gejala - gejalanya saja, mengenai bagaimana memperoleh pengetahuan yang benar, tergantung kepada jenis dan macam pengetahuan. Kant membedakan antara:

a. Pengetahuan a prior

b. metode sintetik,kemudian metode dan jenis pengetahuan itu di gabungkan sehingga menghasilkan empat macam pengetahuan,yaitu:

1) Analitik a priori;

2) Sintetik a priori

3) Analitik a posteriori

4) Sintetik a posteriori.

Tampaknya,metodologi pemikiran Kant dalam memperoleh kebenaran pengetahuan lebih leng-kap dan berimbang.

4. Metode ilmiah dapat memperoleh pengetahuan yang benar dan objektif melalui cara ini, seperti melakukan suatu pendekatan (approach) untuk menentukan lingkupan studi (scope), yang sering disebut objek forma,untuk menentukan metode (method) yang cocok, apakah analisis ataukah sintesis dan peralatan yang sesuai, apakah induktif ataukah 
deduktif dan menentukan sistem kerja yang tepat, apakah terbuka ataukah tertutup, semuanya menjadi penting. Teori-teori pengetahuan/kebenaran ada tiga teori pokok, yaitu teori koherensi, teori korespondensi,dan teori pragmatik.

Ontologi, dalam bahasa Inggris "ontology", berakar dari bahasa yunani "on" berarti ada, dan 'ontos' berarti keberadaan. Sedangkan "logos" berarti pemikiran. Jadi, ontologi adalah pemikiran mengenai yang ada dan keberadaannya. Selanjutnya menurut A.R.Lacey,ontologi di artikan sebagai " $a$ central part of metaphisics" (bagian sentral dari metafisika).

Dalam metafisika, pada dasarnya dipersoalkan mengenai substansi atau hakikat alam semesta ini berhakikat monistik atau pluralistik, bersifat tetap atau berubah-ubah, dan apakah alam semesta ini merupakan kesungguhan(actual) atau kemungkinan (potency).

Beberapa karakteristik ontologi, seperti di ungkapkan oleh bagus,antara lain:

1. Ontologi adalah studi tentang arti"ada"dan "berada",tentang ciri-ciri esensial dari yang ada dalam dirinya sendiri, menurut bentuknya yang paling abstrak.

2. Ontologi adalah cabang filsafat yang mempelajari tata dan struktur realitas dalam arti seluas mungkin, dengan menggunakan kategorikategori seperti: ada atau menjadi, aktualitas atau pontesialitas, nyata atau penampakan, esensi atau eksistensi, kesempurnaan, ruang dan waktu, perubahan dan sebagainya.

3. Ontologi adalah cabang filsafat yang mencoba melukiskan hakikat terakhir yang ada, yaitu yang satu, yang absolut,bentuk abadi, sempurna, dan keberadaan segala sesuatu yang mutlak bergantung kepada-nya.

4. Cabang filsafat yang mempelajari tentang status realitas apakah nyata atau semu, apakah pikiran itu nyata dan sebagainya.

Hakikat abstrak atau jenis menentukan kesatuan (kesamaan) dari berbagai macam jenis, bentuk dan sifat hal-hal atau barang-barang yang berbedabeda dan terpisah-pisah. Perbedaan dan keterpisahan dari orang-orang bernama Socrates, plato, aristoteles, dan sebagai-nya, terikat dalam satu kesamaan sebagai manusia. Manusia,binatang, tumbuhan dan benda-benda lain yang berbeda-beda dan terpisah-pisah, akan tersatukan dengan kesamaan jenis sebagai makhluk. Dalam filsafat, studi mengenai hakikat jenis atau hakikat abstrak ini masuk kedalam bidang metafisika umum (general metaphisics) atau ontologi (ontologi). Oleh sebab itu, pembahasan tentang hakikat jenis ilmu pengetahuan berarti membahas ilmu pengetahuan secara ontologis.

Secara etimologis, "epistemologi" berakar dari bahasa yunani "episteme" yang berarti pengetahuan atau ilmu pengetahuan, dan "logos" yang juga berarti pengetahuan. Jadi, epistemologi berarti pengetahuan mengenai pengetahuan yang sering disebut 'teori pengetahuan (theory of knowledge). Persoalan sentral epistemologi adalah mengenai persoalan apa yang dapat kita ketahui dan bagaiman mengetahuinya, "what can we know, and how do we know if"(Lacey:1976). Lacey selanjutnya menegaskan antara lain bahwa persoalan pokok yang dalam epistemologi adalah "belief, understanding, reason, judgment, sensation, imagination, supposing, guesting, learning and forgetting".

Dalam epistemologi terdapat beberapa perbedaan mengenai teori pengetahuan. Hal ini disebabkan karena setiap ilmu pengetahuan memiliki 
potensi objek metode, sistem dan tingkat kebenaran yang berbeda-beda. Segala macam perbedaan itu terutama berkembang dari perbedaan tajam tentang sudut pandang dan metode yang bersumber dari rasionalisme identik dengan teori koherensi. Dengan kata lain,epistemologi merupakan sutu bidang filsafat nilai yang mempersoalkan tentang hakikat kebenaran, karena semua pengetahuan mempersoalkan tentang kebenaran.

Pengetahuan itu ada yang diperoleh secara langsung melalui sumber kemampuan indra, dan juga diperoleh secara tak langsung melalui penyimpulan akal pikiran. Berdasarkan jenis cara mengetahui ini, dapat dinilai bahwa tingkat kepastian kebenaran yang diperoleh tentu berbeda-beda. Perbedaannya adalah ditentukan oleh 'kemampuan pengindraan setiap orang. Sedangkan kemamouan pengindraan setiap orang dipengaruhi oleh posisi dan kepentingan masingmasing.

Terhadap objek. Kondisi ini masih ditambah lagi dengan fakta bahwa setiap organ indra pun mempunyai kemampuan yang berbeda-beda, bahkan sering saling bertentangan pula antara satu organ dengan yang lain. Rasa keinginan tahuan manusia ternyata menjadi titik perjalanan manusia ternyata takkan pernah usai. Hal inilah yang kemudian melahirkan beragam penelitian dan hipotesa awal manusia terhadap inti dari keanekaragaman realitas. Kemudian dirumuskanlah sebuah teori pengeta-huan dimana pengetahuan menjadi terklasifikasi menjadi beberapa bagian melalui pembedaan inilah kemudian lahir sebuah konsep yang dinamakan ilmu. Pengembangan ilmu terus dilakukan. Akan tetapi disisi lain pemuasan dahaga manusia terhadap rasa keinginan tahuannya seolah tak berujung dan menjebak manusia kelembah kebebasan tanpa batas.

Axiologi adalah istilah yang berasal dari kata yunani yaitu:axios yang berati sesuatu atau wajar. Sedangkan logos yang berarti ilmu, dalam lingkup kajian filsafat nilai merujuk pada pemikiran atau suatu sistem seperti politik. Social dan agama sistem mempunyai rancangan dan aturan sebagai satu bentuk pengendalian terhadap satu institusi dapat terwujud. Pengertian axiologi menurut bahasa yunani, axiologi berasal dari kata axios artinya nilai dan logos artinya teori atau ilmu jadi axiologi adalah teori tentang nilai. Axiologi bisa juga disebut sebagai theory of value atau teori nilai. Berikut ini dijelaskan beberapa definisi. Menurut suriasumantri axiologi adalah kegunaan ilmu pengetahuan bagi kehidupan manusia kajian tentang nilai-nilai khusunya etika Menurut Bramel Aksiologi terbagi tiga bagian:

1. Moral conduct yaitu tindakan moral, bidang ini melahirkan disiplin khusus yaitu etika.

2. Estetic expression yaitu ekspresi keindahan bidang ini melahirkan keindahan.

3. Socio political life yaitu kehidupan social politik, yang akan melahirkanfilsafat sosial politik.

Kata sains berasal dari kata science, scienta, scine yang artinya mengetahui. Dalam kata lain, sains adalah logos, sendi, atau ilmu. Sains dapat diartikan sebagai ilmu pengetahuan yang bertujuan untuk mencari kebanaran berdasarkan fakta atau fenomena alam (Sudjana, 2008: 3-4). Sains yang dipahami dalam arti sebagai pengetahuan obyektif, tersusun, dan teratur tentang tatanan alam semesta. Sains pada wilayah yang sempit atau spesifik dapat dipahami sebagai 
ilmu pengetahuan alam dan pada tataran yang luas dipahami sebagai sagala macam disiplin ilmu pengetahuan.

Djojosoebagio, sebagai-mana dikutip oleh Sudjana mengemukakan beberapa sifat-sifat sains antara lain:

1. Kumulatif, artinya dinamis atau tidak statis karena selalu mencari tambahan ilmu mengingat kebenaran bersifat sementara.

2. Ekonomis untuk penjelasan-penjelasan dan kaidah-kaidah yang kompleks, formulasinya sederhana, susu-nannya ekonomis sehingga dipakai istilah pendek, simbol dan formula.

3. Dapat dipercaya atau diandalkan untuk meramalkan sesuatu dan lebih baik hasilnya daripada pekerjaan berdasarkan perkiraan saja.

4. Mempunyai daya cipta tentang sesuatu

5. Dapat diterapkan untuk menganalisis perilaku atau kejadian-kejadian alamiah.

Ciri-ciri sains menurut Melsen yang dikutip oleh Sudjana dalam buku yang sama antara lain, secara metodis, harus mencapai suatu keseluruhan logika kolumer:

1. Harus tanpa pamrih,

2. Universalisme,

3. Objektifitas,

4. Intersubjektifitas

5. Progresif

Menurut Kamus Besar bahasa Indonesia agama adalah Sistem atau kepercayaan kepada Tuhan, atau juga disebut juga dewa atau nama lainnya dengan ajaran kebhaktian dan kewajiban-kewajiban yang harus bertalian dengan kepercayaan tersebut. Sebagian orang apabila ditanya tentang agama maka jawabannya adalah pegangan hidup yang dianutnya yang memberikan kedamaian. Indonesia merupakan negara pluralitas dan salah satunya dalam hal agama. Terdapat lebih dari 5 agama atau kepercayaan yang dianut oleh masyarakat indonesia antara lain, Islam, Kristen, Katolik, Hindu, Budha, Konghucu, serta kepercayaan masyarakak (Animisme dan Dinamisme).

Dalam bahasa Arab, perkataan "Islam" bermaksud "tunduk" atau "patuh". Jika seorang Muslim ditanya, "Apakah itu Islam?", biasanya dia akan menjawab, "Agama yang tunduk kepada Allah, satu-satu Tuhan yang benar." Tidak hanya bermakna demikian, Islam adalah agama yang diturunkan Allah yang memberikan kesela-matan serta sebagai rahmat bagi seluruh alam yang diturunkan melalui Nabi Muhammad saw yang memiliki kitab suci Al-qur'an sebagai pedoman hidup.

Islam muncul di dunia yang fana ini untuk memberikana solusi serta menjawab permasalahan-permasalahan hidup yang dialami oleh manusia. Islam bukanlah satu golongan, kepentingan kelompok tertentu ataupun kepentingan politik lainnya dan juga Islam bukanlah semata-mata untuk umat Islam itu sendiri. Lebih dari itu, Islam diturunkan oleh Allah dengan suatu visi dan misi, yaitu untuk menyebarkan kebaikan dan keselamatan serta rahmat bagi seluruh alam.

Abad ke-15, pengetahuan ilmiah dikuasai oleh sedikit sistem utama yang bersifat statis dan dogmatis. Terutama fisika Aristotelian, sistem astronomi Ptolemic, Kedokteran Galen, dan Kimia Jabirian, sehingga ilmu pengetahuan menjadi sukar ditempuh dan berkembang lebih lanjut (Hassan, 2008:63-64). 
Benturan agama dan sains telah dimulai sejak saat itu. Dimana pemegang kekuasaan tertinggi adalah Gereja.

Ajaran Gereja sangatlah dominan, dimana segala pengetahuan haruslah sejalan dengan Injil. Ilmu pengetahuan dikendalikan oleh gereja dan pendeta atau biarawan. Apabila tidak sependapat maka dianggap sesat dan akan dibunuh. Hal ini mendorong semangat Renaissance untuk melakukan suatu perlawanan dalam upaya pembebasan akal dari kekangan dan belenggu gereja dan menjadikan fakta empirik sebagai sumber pengatahuan dan tidak lagi bertolak pada filsafat Yunani seutuhnya yang menjadi dasar filsafat Kristen dengan Injilnya. Hal ini menunjukkan kelangkaan ilmiah di Eropa pertengahan abad ke-14 dan ke-15.

Untuk mengatasi masalah tersebut maka diperlukan sebuah pembaharuan atau pergeseran sistem sistem yang dominan tersebut. Dengan kata lain diperlukan sebuah revolusi dalam rangka pembebasan akal dari dominasi Gereja.

Revolusi ilmiah pertama dimulai oleh Copernicus pada tahun 1543, tetapi aktifid ini tidak efektif hingga pertengahan abad ke17. Pada abad ke-12 Eropa menga-lami Renaissane dalam sains. Akhir abad tersebut, karya-karya bahasa arab diterjemahkan ke bahasa latin. Selama empat abad (ke-12 sampai ke-16), ilmu pengetahuan Eropa tidak membantu apa yang diterjemahkan dari karya yang berbahasa arab, dan pada abad ke-17 barulah revolusi ilmiah benar-benar dimulai (Hassan, 2008 : 64).

Beberapa tokoh Renaissance antara lain Nicolaus Copernicus (1473-1543) dengan pandangan Heliosen-trisnya, yaitu teori mengenai Matahari sebagai pusat tata surya. Teori ini didukung oleh Johannes Kepler (1571-1630) dan Galileo Galilei (1564-1643). Dan juga Fransis Bacon (1561-1626) dengan teknik berfikir induktifnya, yang berbeda dengan teknik deduktif Aristoteles (logika silogisme) yang diajarkan pada abad pertengahan (Sudjana, $2008: 6$ ).

Pemikiran tokoh Renaisance tersebut dianggap bertentangan dengan gereja yang memiliki pandangan Geosentris yaitu Bumi sebagai pusat tata surya. Otoritas gereja saat itu tidak dapat ditentang sehingga mereka mengalami penyiksaan dibakar hidup-hidup oleh Gereja karena kokoh memegang apa yang diyakininya.

Selanjutnya datanglah masa pencerahan (aufkla-rung) pada abad XVII yang dirintis oleh Isaac Newton (1642-1727), sebagai perkembangan lebih jauh dari Ra-sionalisme dan Empirisme dari abad sebelumnya dimana fokus pembahasannya adalah pemberian interpretasi baru terhadap dunia, manusia dan Tuhan. Sementara pada abad aufklarung pembahasannya lebih luas mencakup segala aspek kehidupan manusia (Sudjana, $2008: 8$ ).

Agama dan Sains tidak selamanya berada dalam pertentangan dan ketidaksesuaian. Banyak kalangan yang berusaha mencari hubungan antara keduanya. Sekelompok orang berpendapat agama tidak mengarahkan pada jalan yang dikehendakinya dan agama juga tidak memaksakan sains untuk tunduk pada kehendaknya. Kelompok lain berpandapat bahwa sains dan agama tidak akan pernah dapat ditemukan, keduanya adalah entitas yang berbeda dan berdiri sendiri, memiliki wilayah yang terpisah baik dari segi objek formalmaterial, metode penelitian, kriteria kebenaran, serta peran yang dimainkan.

Pandangan beberapa pakar terhadap hubungan antara sain dan agama diantaranya seperti:

| RI'AYAH, Vol. 4 No. 01 Januari-Juni 2019 


\section{Tipologi Ian G. Barbour}

a. Konflik

Pandangan konflik ini mengemuka pada abad ke-19, dengan tokohtokohnya seperti: Richard Dawkins, Francis Crick, Steven Pinker, serta Stephen Hawking. Pandangan ini menempatkan sains dan agama dalam dua ekstrim yang saling bertentangan. Bahwa sains dan agama memberikan pernyataan yang berlawanan sehingga orang harus memilih salah satu di antara keduanya. Menolak agama dan menerima sains, atau sebaliknya. Masing-masing menghimpun penganut dengan mengambil posisi-posisi yang bersebrangan. Sains menegaskan eksistensi agama, begitu juga sebaliknya. Keduanya hanya mengakui keabsahan eksistensi masing-masing. Agama dan sains adalah dua ekstrim yang saling bertentangan, saling menegaskan kebenaran lawannya.

Barbour menanggapi hal ini dengan argumen bahwa mereka keliru apabila melanggengkan dilema tentang keharusan memilih antara sains dan agama. Kepercayaan sebuah agama menawarkan kerangka makna yang lebih luas dalam kehidupan. Sedang-kan sains tidak dapat mengungkap rentang yang luas dari pengalaman manusia atau mengartiku-lasikan kemungkinan-kemungkinan bagi tranfor-masi hidup manusia sebagaimana yang dipersak-sikan oleh agama(Barbour, 2006 : 224). Dalam konflik pertentangan dipetakan dalam 2 bagian yang berseberangan:

1. Materialisme ilimiah, menganggap bahwa materi sebagai realita dasar alam (pentingnya realitas empiris), sekaligus meyakini bahwa metode ilmiah adalah satu-satunya cara yang sahih untuk mendapatkan pengetahuan.

2. Literalisme kitab suci merupakan satu-satunya sumber kebenaran adalah kitab suci, karena dianggap sebagai sekumpulan wahyu yang bersifat kekal dan benar karena bersumber dari Tuhan, sehingga tak memungkinkan bersumber dari yang lain termasuk alam semesta.

\section{a. Independensi}

Memisahkan agama dan sains dalam wilayah yang berbeda, memiliki bahasa yang berbeda, berbicara mengenai hal-hal yang berbeda, berdiri sendiri membangun independensi dan otonomi tanpa saling mempengaruhi. Agama mencakup nilai-nilai, sedangkan sains berhubungan dengan fakta. Dibedakan berdasarkan masalah yang ditelaah, domain yang dirujuk dan metode yang digunakan.

Menurut Barbour (2006:66) menyatakan bahwa Tuhan adalah transendensi yang berbeda dari yang lain dan tidak dapat diketahui kecuali melalui penyingkapan diri. Keyakinan agama sepenuhnya bergantung pada kehendak Tuhan, bukan atas penemuan manusia sebagaimana halnya sains. Saintis bebas menjalankan aktivitas mereka tanpa keterlibatan unsur teologi, demikian pula sebaliknya, karena metode dan pokok persoalan keduanya berbeda. Sains dibangun atas pengamatan dan penalaran manusia sedangkan teologi berda-sarkan wahyu Ilahi. Barbour mencermati bahwa pandangan ini sama-sama akan mempertahankan karakter unik dari sains dan agama. Namun demikian, manusia tidak boleh merasa puas dengan 
pandangan bahwa sains dan agama sebagai dua domain yang tidak koheren. Agama dan sains adalah dua domain yang terpisah yakni agama atau Tuhan hanya dapat dikenal sebagaimana yang diwahyukan, tidak dapat diketahui kecuali melalui penyingkapan diri. Sedangkan sains dapat dikenali melalui fenomena dan empiris. Sains dibangun berdasarkan pengama-tan dan penalaran manusia, sedangkan teologi berdasarkan wahyu.

Sains dan agama ditafsirkan sebagai dua bahasa yang tidak saling berkaitan karena fungsi masing-masing berbeda. Bahasa agama adalah sebuah seperangkat pedoman yang menawarkan jalan hidup yang berprinsip pada moral tertentu, sedangkan sains dianggap sebagai serangkaian konsep untuk memprediksi dan mengontrol alam.

b. Dialog

Pandangan ini menawarkan hubungan antara sains dan agama dengan interaksi yang lebih konstruktif daripada pandangan konflik dan independensi. Diakui bahwa antara sains dan agama terdapat kesamaan yang bisa didialogkan, bahkan bisa saling mendukung satu sama lain. Dialog yang dilakukan dalam membandingkan sains dan agama adalah menekankan kemiripan dalam prediksi metode dan konsep. Salah satu bentuk dialognya adalah dengan membandingkan metode sains dan agama yang dapat menunjukkan kesamaan dan perbedaan. Namun, dialog tidak menawarkan kesatuan konseptual sebagaimana diajukan pan-dangan integrasi. Mengutamakan tingkat kesejajaran antara sains dan agama. dan konsep.

Dialog menekankan kemiripan dalam pra anggapan, metode

1. Pra anggapan dan pertanyaan batas, memunculkan pertanyaan batas, mengajukan sebuah pertanyaan fundamental, ilmuwan dan agamawan dapat bekerja sama untuk menjelaskan.

2. Kesamaan suatu metodologis dan konseptual, Sains tak selamanya obyektif, agama tidak selamanya subyektif.

Barbour (2006:32) memberikan contoh masalah yang didialogkan ini dengan digunakannya model-model konseptual dan analogi-analogi ketika menjelaskan hal-hal yang tidak bisa diamati secara langsung. Dialog juga bisa dilakukan untuk menjawab pertanyaan-pertanyaan tentang ilmu pengetahuan yang mencapai tapal batas. Seperti: mengapa alam semesta ini ada dalam keteraturan yang dapat dimengerti? dan sebagainya. Ilmuwan dan teolog dapat menjadi mitra dialog dalam menjelaskan fenomena tersebut dengan tetap menghormati integritas masing-masing.

Dalam menghubungkan agama dan sains, pandangan ini dapat diwakili oleh pendapat Albert Einstein, yang mengatakan bahwa "Religion without science is blind: science without religion is lame". Tanpa sains, agama menjadi buta, dan tanpa agama, sains menjadi lumpuh. Demikian pula pendapat David Tracy, seorang teolog Katolik yang menya-takan adanya dimensi religius dalam sains bahwa intelijibilitas dunia memerlukan landasan rasional tertinggi yang 
bersumber dalam teks-teks keaga-maan klasik dan struktur pengalaman manu-siawi (Barbour, 2006:76).

c. Integrasi

Pandangan ini melahirkan hubungan yang lebih bersahabat daripada pendekatan dialog dengan mencari titik temu diantara sains dan agama. Sains dan doktrin-doktrin keagamaan, sama-sama diang-gap valid dan menjadi sumber koheren dalam pan-dangan dunia. Bahkan pemahaman tentang dunia yang diperoleh melalui sains diharapkan dapat memperkaya pemahaman keagamaan bagi manusia yang beriman.

Ada beberapa pendekatan yang digunakan dalam hubungan integrasi ini. Pendekatan pertama, berangkat dari data ilmiah yang menawarkan bukti konsklusif bagi keyakinan agama, untuk memperoleh kesepakatan dan kesadaran akan eksistensi Tuhan. Pendekatan kedua, yaitu dengan menelaah ulang doktrin-doktrin agama dalam relevansinya dengan teori-teori ilmiah, atau dengan kata lain, keyakinan agama diuji dengan kriteria tertentu dan dirumuskan ulang sesuai dengan penemuan sains terkini. Lalu pemikiran sains keagamaan ditafsirkan dengan filasafat proses dalam kerangka konseptual yang sama. Demikian Barbour menjelaskan tentang hubungan integrasi ini (Ian G. Barbour 2006:42 ).

\section{Tipologi versi John Haught (1995)}

Menurut Haught, hubungan agama dan sains yang diawali dengan titik konflik antara agama dan sains untuk mengurangi konflik, dilakaukan pemisahan yang jelas batas-batas agama dan sains agar tampak menjadi kontras/perbedaaan keduanya. Jika batas keduanya sudah terlihat, langkah berikutnya adalah mengupayakan agar keduanya berdialog / kontak. Setelah tahap ini dapat ditemukan kesamaan tujuan yaitu mencapai pema-haman yang benar tentang alam, selanjutnya antara agama dan sains saling melengkapi/ konfirmasi.

Islam adalah agama yang sangat menganjurkan umatnya untuk saling mengerahkan segala kemampuannya dalam menggunakan akalnya serta memikirkan segala apa yang ada di alam semesta ini. Hal ini sebagaimana tercantum dalam ayat Al-Qur'an surat Ar-Rahman ayat 33 yang artinya "Hai jama'ah jin dan manusia, jika kamu sanggup menembus (melintasi) penjuru langit dan bumi, Maka lintasilah, kamu tidak dapat menembusnya kecuali dengan kekuatan".

Dalam ayat tersebut Allah saw memberikan kesempatan kepada manusia untuk melakukan pemikiran (menggunakan akalnya) dan eksplorasi terhadap alam semesta. Upaya penaklukan ruang angkasa harus dilihat sebagai suatu ibadah manusia yang ditujukan selain untuk memahami rahasia alam, juga demi masa depan kehidupan manusia.

Menurut Muhammad Ismail sebagaimana dikutip oleh Sudjana (2008: 12) mengatakan bahwa pemahaman Islam tidak lain adalah pemikiran-pemikiran yang memiliki penunjukan-penunjukan nyata, yang dapat ditangkap dengan logika selama masih dalam batas jangkauan akalnya. Namun, bila hal-hal tersebut berada diluar jangkauan akalnya, 
maka hal itu ditunjukan secara pasti oleh sesuatu yang dapat diindera, tanpa rasa kera-guan sedikitpun. Dengan demikian peranan akal bagi manusia sangatlah penting dan mendasar karena dengan akalnya ia dapat menentukan yang terbaik bagi dunia dan akhirantnya kelak. Rasulullah saw pernah mengatakan bahwa tidak ada agama (Islam) tanpa adanya aktifitas akal. Artinya bagi seorang muslim, keyakinannya tentang Islam haruslah dibangun berdasarkan akal sehat dan penalarannya. Bukan hanya sekedar dogma yang dipaksakan atau informasi-informasi tanpa kenyataan. Akan tetapi, akal harus difungsikan sebagaimana mestinya (Sudjana, 2008:13).

Allah SWT telah menurunkan mukjizat yang sangat berharga demi kelangsungan hidup manusia kepada nabi Muhammad saw berupa $\mathrm{Al}$ Qur'anulkarim. Al-Qur'an adalah kitab suci umat Islam yang menjadi pedoman hidup serta menyempurnakan kitab yang diturunkan kepada nabi-nabi dan rasul sebelum nabi Muhammad saw. Al-Qur'an bukan hanya sekedar kitab suci bagi umat Islam, tetapi Al-Qur'an bersifat universal yakni diperuntukkan untuk seluruh umat manusia. Al-Qur'an merupakan rujukan dari berbagai macam ilmu pengetehuan. Al-Qur'an bukanlah kitab sains, tetapi segala pengetahuan tentang sains hendaknya dirujukkan kedalam Al-Qur'an. Al-Qur'an secara eksplisit telah menerangkan tentang segala apa yang ada dan terjadi dibumi ini dan dengan sains lah kita membuktikannya. Osman Bakar (1994:75) mengutip dari Brunner mengatakan bahwa seorang ilmuwan Muslim yang termashyur yaitu Ibnu Sina mengatakan jikalau sebuah sains disebut sains yang sejati apabila ia menghubungkan pengetahuan tentang dunia dengan pengetahuan tentang prinsip Illahi.

\section{Kesimpulan}

Ilmu berasal dari kata "alima" (bahasa arab) yang berarti tahu, jadi ilmu maupun science secara etimologis berarti pengetahuan. "Science" berasal dari kata scio, scire (bahasa latin yang artinnya tahu). Secara terminologis ilmu dan science punya pengertian yang sama yaitu pengetahuan. yang punya ciri-ciri: Ralfh Ross dan ernest Van Den Haag menulis bahwa ilmu itu empirical, rasional, yang umum dan bertimbun bersusun dan ke empatnya serentak. Ilmu itu sendiri terbagi menjadi 2 bagian yaitu: Ilmu pengetahuan (ilmu yang ilmiah) dan Ilmu Non pengetahuan. Objek ilmu pengetahuan itu ada yang berupa materi (objek materi) dan ada yang berupa bentuk (objek formal). Objek materi adalah sasaran material suatu penyelidikan, pemikiran, atau penelitian keilmuan bisa berupa benda-benda material maupun yang nonmaterial, bisa pula berupa hal-hal, masalah-masalah, ide-ide dan konsep-konsep. Sumber ilmu pengetahuan ada beberapa macam yaitu empirisme, rasionalisme, intuisi, dan wahyu.

Agama dan sains tidak selamanya berada dalam pertentangan dan ketidaksesuaian. Banyak ilmuwan yang berusaha mencari hubungan antara keduanya. Sains dan agama merupakan dua entitas yang berbeda, namun keduanya sama-sama memiliki peranan sangat penting dalam kehidupan manusia. Agama merupakan petunjuk yang dipedomankan melalui aturan dalam kitab suci sedangkan sains berpijak pada interaksi serta komunikasi yang terbangun dalam masyarakat. Keduanya akan bergandeng pada proses prilaku, moral, etika, stratafikasi sosial dan struktur masyarakat. 


\section{Daftar Pustaka}

Amroeni Drajat, Filsafat IslamBuat yang Pengen Tahu, Jakarta: Erlangga, 2006.

Amsal Bakhtiar, Filsafat Agama 1, Jil.I.Cet. I: Pa-mulang Timur, Ciputat: Lolos Wacana Ilmu, 1997.

Basuki, Penelitian Kualitatif untuk Ilmu-Ilmu Kema-nusiaan dan Budaya, Universitas Gunadarma, 2006

Departemen Pendidikan Nasional, Kamus besar Bahasa Indonesia, Edisi 3, Jakarta: Balai Pustaka, 2003.

Depdiknas, Kamus Bahasa Indonesia, Pusat Bahasa Departemen Pendidikan Nasional, 2008.

Depdiknas, Kamus besar bahasa indonesia, Jakarta: Balai Pustaka, 2003.

Depdiknas, Kamus Tesaurus Bahasa Indonesia, Pusat Bahasa Departemen Pendidikan Nasional, 2008.

Eggi Sudjana, Islam Fungsional, Jakarta: PT Raja Grafindo Persada, 2008.

Endang Syaifuddin Anshari, Ilmu Filsafat dan Agama, Surabaya: PT. Bina Ilmu, 1987.

F. Budi Hardiman, Ruang Publik, Yogyakarta: Kanisius, 2010.

H. Noeng Muhadjir, Filsafat Ilmu: Positivisme, Post positivism dan Post Modernisme, Yogyakarta: Rake Sarasin, 2001.

H.Mohammad Daud Ali, Pendidikan Agama Islam, Jakarta: PT. Raja Grafindo Persada, 1998.

Herabudin, Ilmu Alamiah Dasar, Bandung: Pustaka Setia, 2010.

Husain Heriyanto, Paradigma Holistik Dialog Filsa-fat, Sains dan Kehidupan Menurut Shadra dan White-head, Jakarta Selatan: Teraju, 2003.

Ian Gunawan Barbour, Isu dalam Sains danAgama, Yogyakarta: UIN Sunan Kalijaga, 2006.

KomaruddinYooke Tjuparmah, Kamus Istilah Karya Tulis Ilmiah, Jakarta: Bumi Aksara, 2002

Kuntowijoyo, Paradigma Islam Interpretasi untuk Aksi, Bandung: Mizan, 1998.

Lorens Bagus, Kamus Filsafat, Ed. I.Cet.III, Jakar-ta: Gramedia, 2002.

Mawardi dan Nur Hidayat, Ilmu Alamiah Dasar-Ilmu Sosial Dasar-Ilmu Budaya Dasar.Bandung: CV. Pustaka Setia, 2007.

Noerhadi, Filsafat Ilmu Pengetahuan, Jakarta: Pascasarjana Universitas Indonesia, 1998.

Nursalam, Konsep dan Penerapan Metodologi Penelitian Ilmu Keperawatan, Jakarta: Salemba Medika, 2003.

Osman Bakar, Tauhid \& Sains: Essai-essai tentang sejarah dan Filsafat Islam Sain, Bandung: Pustaka Hidayah, 1994.

Peraturan Pemerintah Republik Indonesia, tentang Pengamanan Rokok bagi Kesehatan, Nomor 81 Tahun, 1999.

Poedja Wijatna, Tahu dan Pengetahuan, Jakarta: Rineka Cipta, 2004. 
Poerwandari, Pendekatan Kualitatif dalam Pe-nelitian Psikologi. Jakarta: Lembaga Pengembangan Sarana Pengukuran dan Pendidikan Psikologi (LPSP3) Fakultas Psikologi Universitas Indonesia, 1998.

Reza Wattimena, Filsafat dan Sains Sebuah Pen-gantar, Jakarta: PT. Grasindo, 2008.

Ridwan Effendi, Ilmu Sosial dan Budaya Dasar, Jakarta: Kencana Prenada Media Group, 2006.

Sedarmayanti, Sumber Daya Manusia dan Produk-tivitas Kerja, Bandung: Mandar Maju, 2002.

Soekidjo Notoatmodjo, Metodologi Penelitian Kesehatan, Jakarta: PT Rineka Cipta, 2003.

Soetrisno dan Rita Hanafie, Filsafat Ilmu dan Me-todologi Penelitian, Yogyakarta: CV, Andi Offset, 2007.

Sugiyono, Metode Penelitian Kuantitatif Kualitatif dan RED, Bandung: Alfabeta, 2007.

Suhartono suparlan, Filsafat Ilmu Pengetahun, Yog-yakarta: Ar-Ruzz Media, 2005.

Sumaryono, Hermeneutik: Sebuah Metode Filsa-fat, Yogyakarta: Penerbit Kanisius, 1993.

Suparlan, Paradigma Naturalistik dalam Peneli-tian Pendidikan: Pendekatan Kualitatif dan Peng-gunaannya, Majalah Antropologi Indonesia. No. 53. Vol. 21, Jurusan Antropologi FISIP Universitas Indonesia, 1997. 